\title{
Locking the Dimeric $\mathrm{GABA}_{\mathrm{B}}$ G-Protein-Coupled Receptor in Its Active State
}

\author{
Julie Kniazeff, ${ }^{1}$ Pierre-Philippe Saintot, ${ }^{1}$ Cyril Goudet, ${ }^{1}$ Jianfeng Liu, ${ }^{1}$ Annie Charnet, ${ }^{2}$ Gilles Guillon, ${ }^{2}$ and \\ Jean-Philippe Pin ${ }^{1}$ \\ ${ }^{1}$ Laboratory for Functional Genomic, Department of Molecular Pharmacology, Centre National de la Recherche Scientifique Unité Propre de Recherche- \\ 2580, and ${ }^{2}$ Institut National de la Santé et de la Recherche Médicale U469, 34094 Montpellier Cedex 5, France
}

\begin{abstract}
G-protein-coupled receptors (GPCRs) play a major role in cell- cell communication in the CNS. These proteins oscillate between various inactive and active conformations, the latter being stabilized by agonists. Although mutations can lead to constitutive activity, most of these destabilize inactive conformations, and none lock the receptor in an active state. Moreover, GPCRs are known to form dimers, but the role of each protomer in the activation process remains unclear. Here, we show that the heterodimeric GPCR for the main inhibitory neurotransmitter, the $\mathrm{GABA}_{\mathrm{B}}$ receptor, can be locked in its active state by introducing two cysteines expected to form a disulphide bridge to maintain the binding domain of the $\mathrm{GABA}_{\mathrm{B} 1}$ subunit in a closed form. This constitutively active receptor cannot be inhibited by antagonists, but its normal functioning, activation by agonists, and inhibition by antagonists can be restored after reduction with dithiothreitol. These data show that the closed state of the binding domain of $\mathrm{GABA}_{\mathrm{B} 1}$ is sufficient to turn $\mathrm{ON}$ this heterodimeric receptor and illustrate for the first time that a GPCR can be locked in an active conformation.
\end{abstract}

Key words: receptor; baclofen; GABA; metabotropic glutamate receptor; glutamate; activation mechanism

\section{Introduction}

G-protein-coupled receptors (GPCRs) play a major role in cellcell communication, especially in the brain, where they are involved in the tuning of fast synaptic transmission. Several classes of GPCRs can be defined based on sequence similarity (Kolakowski, 1994; Bockaert and Pin, 1999; Fredriksson et al., 2003). GPCRs for the two main neurotransmitters, GABA and glutamate [the $\mathrm{GABA}_{\mathrm{B}}$ and metabotropic glutamate receptors (mGluRs)] are part of the class III GPCRs, together with those activated by $\mathrm{Ca}^{2+}$, sweet molecules, and some pheromones (Pin et al., 2003). These receptors form dimers, but the $\mathrm{GABA}_{\mathrm{B}}$ receptor is an obligatory heterodimer constituted of the homologous $\mathrm{GABA}_{\mathrm{B} 1}$ and $\mathrm{GABA}_{\mathrm{B} 2}$ subunits (Jones et al., 1998; Kaupmann et al., 1998; White et al., 1998). $\mathrm{GABA}_{\mathrm{B} 1}$ is responsible for GABA recognition (Galvez et al., 2000a; Kniazeff et al., 2002), whereas $\mathrm{GABA}_{\mathrm{B} 2}$ is necessary for the correct trafficking of $\mathrm{GABA}_{\mathrm{B} 1}$ to the cell surface (Margeta-Mitrovic et al., 2000; Pagano et al., 2001) and is involved in G-protein activation (Galvez et al., 2001;

\footnotetext{
Received July 1, 2003; revised Nov. 10, 2003; accepted Nov. 10, 2003.

This work was supported by grants from the Centre National de la Recherche Scientifique (CNRS), Action Concertée Incitative "Molécules et Cibles Thérapeutiques" from Institut National de la Santé et de la Recherche Médicale, and the French government (J.P.P.). J.L. and A.C. were supported by Groupement d'Intérêt Public Hoechst Marion Roussel/Aventis and CisBio International, respectively. J.K. and C.G. were supported by CNRS and Fondation pour la Recherche Médicale fellowships, respectively. We thank Drs. T. Galvez, G. Labesse, J. Neyton, M. L. Parmentier, L. Prézeau, and P. Paoletti for constructive discussions and critical reading of this manuscript. We also thank Drs. W. Froestl and K. Kaupmann (Novartis, Basel, Switzerland) for the supply of $\mathrm{GABA}_{B}$ ligands and Dr. P. Rondard for the construction of $\triangle \mathrm{GB} 1$ and $\Delta \mathrm{GB} 2$.

Correspondence should be addressed to Dr. Jean-Philippe Pin, Laboratory for Functional Genomic, Centre National de la Recherche Scientifique Unité Propre de Recherche-2580, Department of Molecular Pharmacology, 141 rue de la Cardonille, F-34094 Montpellier Cedex 5, France. E-mail: jppin@ccipe.cnrs.fr.

DOI:10.1523/JNEUROSCI.3141-03.2004

Copyright $\odot 2004$ Society for Neuroscience $\quad 0270-6474 / 04 / 240370-08 \$ 15.00 / 0$
}

Margeta-Mitrovic et al., 2001b; Robbins et al., 2001; Duthey et al., 2002).

The ligand-binding site of class III GPCRs is located in a large extracellular domain (Takahashi et al., 1993) homologous to some periplasmic-binding proteins (O'Hara et al., 1993) and to the binding domain of other receptors such as ionotropic glutamate, atrial natriuteric peptide (ANP), and some tyrosine kinase receptors (Felder et al., 1999; Vicogne et al., 2003). X-ray structures have been solved for the extracellular domains of mGluR type 1 (mGlu1) (Kunishima et al., 2000; Tsuchiya et al., 2002) and ANP receptor (ANPR) types A and C (He et al., 2001; van den Akker, 2001) produced as soluble proteins. These domains are bilobate proteins often called Venus flytrap modules (VFTMs) and share similar sequence homology with the extracellular domain of the $\mathrm{GABA}_{\mathrm{B}}$ subunits (Fig. 1a). The mGlu1 VFTM was observed either in an open or closed conformation, whereas that of the ANPR is only found in a closed conformation.

Both mGlul and ANP VFTMs homodimerize at the level of their lobe I, leaving the two lobe II (connected to the membrane domain) far apart in the absence of agonists (Fig. 1b,c). In the presence of agonists, a change in conformation brings together lobe II, possibly forcing the membrane domains to interact differently (Fig. 1b,c). In the case of mGlu1, this results from: (1) closure of at least one VFTM; and (2) a change in the relative orientation of the VFTMs (Fig. 1b). In the case of the ANPR, this results from the binding of ANP between the two VFTMs (Fig. 1c). Whether the dimer of $\mathrm{GABA}_{\mathrm{B}} \mathrm{VFTMs}$ functions like that of mGlu or ANPRs remains unknown.

Here, we show that the introduction of two cysteines expected to lock the $\mathrm{GABA}_{\mathrm{B} 1}$ VFTM in a closed state by a disulphide bridge is sufficient to lock the entire receptor in an almost fully active 

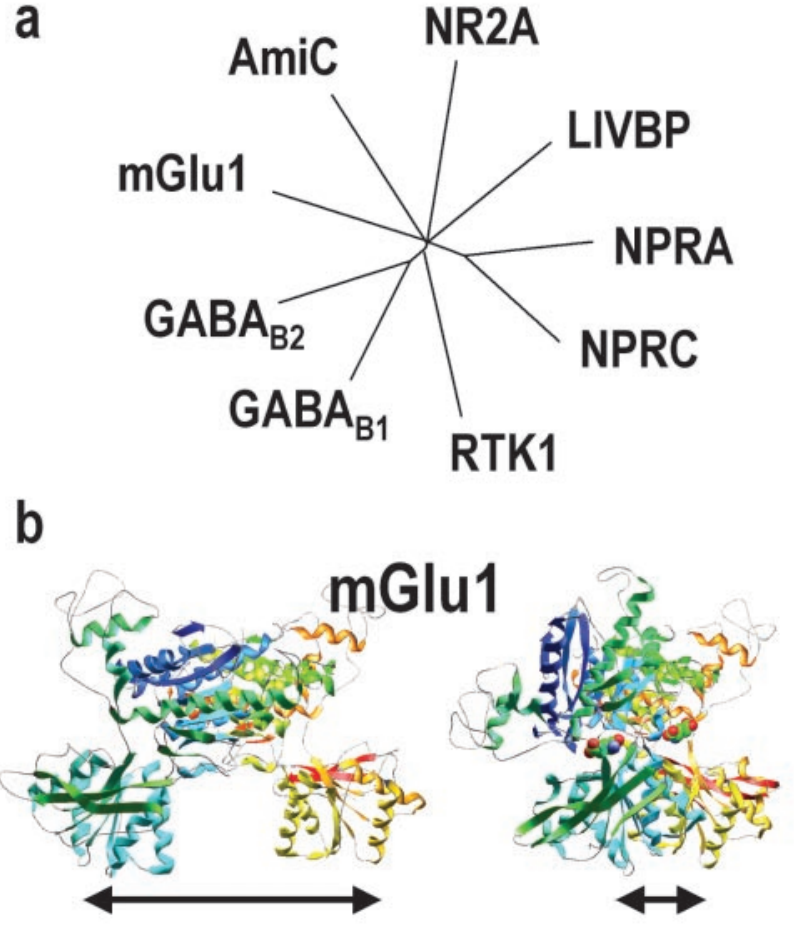

C
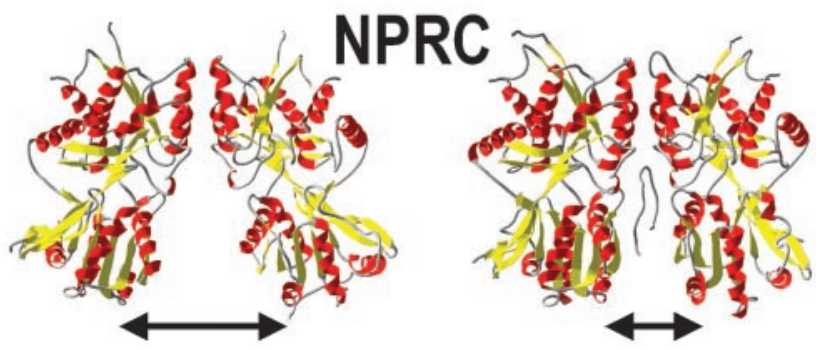

Figure 1. Phylogenic analysis of various VFTMs ( $a$ ) and comparison of the inactive and active conformations of mGlu1 ( $b$ ) and NPRC ( $c$ ) VFTM dimers. $a$, The phylogenetic tree was constructed using the sequences of the VFTMs of the mGlu1 receptor, the amide-binding protein (AmiC) from the amidase operon, the NR2A subunit of the rat NMDA receptor, leucineisoleucine-valine-binding protein (LIVBP), the natriuretic peptide receptor types $A$ and C (NPRA and NPRC, respectively), RTK1 from Schistosoma mansoni, and the rat $G A B A_{B 1}$ and $G A B A_{B 2}$ subunits. Only branches with bootstrap values $>600$ are shown. Note that the RTK1 VFTM is closer to the $G_{A B A}$ VFTMs than to any other VFTMs. $b$, Ribbon view of the inactive (left; $p d b$ : 1ewt) and active (right; pdb:1ewk) forms of the dimer of mGlu1 VFTMs. Note the change in the relative orientation between the two VFTMs and the closure of one VFTM (the blue-green one in front) that bring together lobe II. c, Ribbon view of the inactive (left; pdb:1jdn) and active (right; pdb:1jdp) forms of the dimer of NPRC VFTMs. Note that ANP binding at the interface between the two VFTMs brings together lobe II.

state. This reveals a similar activation mechanism for mGlu and $\mathrm{GABA}_{\mathrm{B}}$ receptors and represents the first example of a GPCR that has been locked in its active state. As such, this study brings much information on the way the GPCRs for the main neurotransmitters, glutamate and GABA, are activated.

\section{Materials and Methods}

Materials. GABA, baclofen, and CGP64213 were gifts from Drs. W. Froestl and K. Kaupman (Novartis Pharma, Basel, Switzerland). $\left[{ }^{125}\right.$ I] CGP64213 was purchase from Anawa (Zurich, Switzerland). FBS, culture media, and other solutions used for cell culture were from Invitrogen-Life Technologies, Inc. (Cergy Pontoise, France). [ $\left.{ }^{3} \mathrm{H}\right]$ Myoinositol $(23.4 \mathrm{Ci} / \mathrm{mol})$ was purchased from PerkinElmer Life Sciences
(Paris, France). All other reagents used were of molecular or analytical grade, where appropriate.

Phylogenetic analysis. Sequence alignment of the VFTMs of crystallized amide-binding protein AmiC (pdb:1pea), leucine-isoleucine-valinebinding protein (pdb: 2liv), natriuretic peptide receptors A and C (pdb: $1 \mathrm{dp} 4$ and $1 \mathrm{jdn}$, respectively), and mGlu1 (pdb:1ewk) was deduced after superimposition of their structures using SwissPdbViewer (version 3.7) (Guex and Peitsch, 1997). Sequences of VFTMs of the rat NR2A subunit of the NMDA receptor, $\mathrm{GABA}_{\mathrm{B} 1}$ and $\mathrm{GABA}_{\mathrm{B} 2}$ subunits (GB1 and GB2), and tyrosine kinase receptor type 1 (RTK1) from Schistosoma mansoni were aligned on the structural multiple alignment according to Paoletti et al. (2000), Kniazeff et al. (2002), and Vicogne et al. (2003), respectively. The phylogenetic tree was then constructed using the neighbor-joining method (Saitou and Nei, 1987) with the command interface of the Clustal W 1.60 program (Thompson et al., 1994) using the default parameters and not excluding gaps. Bootstrap values were calculated using 1000 trials with seeds of 111 . The tree was drawn using TreeView (version 1.6.2) (Page, 1996).

Molecular modeling. Three-dimensional models of the open and closed forms of $\mathrm{GABA}_{\mathrm{B} 1}$ VFTM were built as described previously (Kniazeff et al., 2002) using Modeler $6.0 \alpha$ (Sali and Blundell, 1993). In silico mutagenesis and disulphide bridges modeling were performed using the SwissPdbViewer program (version 3.7) (Guex and Peitsch, 1997) and software default parameters. The figures were prepared using SwissPdbViewer.

Plasmids and site-directed mutagenesis. The plasmids encoding the wild-type $\mathrm{GABA}_{\mathrm{B} 1 \mathrm{a}}$ and $\mathrm{GABA}_{\mathrm{B} 2}$ subunits epitope tagged at their $\mathrm{N}$-terminal ends (pRK-GABA $\mathrm{B}_{1 \mathrm{a}}$-HA and pRK-GABA $\mathrm{B}_{\mathrm{B} 2}-\mathrm{cMyc}$ ), under the control of a cytomegalovirus promoter, were described previously (Galvez et al., 2001; Pagano et al., 2001).

Mutant subunits, carrying single or multiple mutations, were obtained using the Quick-Change strategy (Stratagene, La Jolla, CA). Briefly, for each mutagenesis, two complementary 27-mers primers (Eurogentec, Bruxelles, Belgium) were designed to contain the desired mutation. To allow a rapid screening of mutated clones, primers carried an additional silent mutation introducing a new restriction site. The presence of the desired mutations and the absence of additional ones were confirmed by DNA sequencing (Genaxis, Nîmes, France). For double mutants, two Quick-Change reactions were performed successively.

Cell culture and expression in HEK 293. Human embryonic kidney (HEK) 293 cells were cultured in DMEM supplemented with 10\% FCS and transfected by electroporation as described previously (Brabet et al., 1998; Franek et al., 1999). Unless stated otherwise, $10 \times 10^{6}$ cells were transfected with plasmid DNA containing hemagglutinin (HA)-tagged $\mathrm{GABA}_{\mathrm{B} 1}(2 \mu \mathrm{g})$ and cMyc-tagged $\mathrm{GABA}_{\mathrm{B} 2}(2 \mu \mathrm{g})$ and were completed to a total amount of $10 \mu \mathrm{g}$ of plasmid DNA with $\mathrm{pRK}_{6}$. For determination of inositol phosphate (IP) accumulation, the cells were also transfected with the chimeric G $\alpha$ qi9 G-protein, which allows the coupling of the recombinant heteromeric $\mathrm{GABA}_{\mathrm{B}}$ receptor to phospholipase C (PLC) (Franek et al., 1999).

Determination of IP accumulation. Determination of IP accumulation in transfected cells was performed in 96-well plates $\left(0.2 .10^{6}\right.$ cells/well $)$ after overnight labeling with ${ }^{3} \mathrm{H}$-myo-inositols $(0.5 \mu \mathrm{Ci} /$ well $)$, as described previously (Chengalvala et al., 1999), with some modifications. The stimulation was conducted for $30 \mathrm{~min}$ in a medium containing 10 $\mathrm{mm} \mathrm{LiCl}$ and the indicated concentration of agonist or antagonist. The reaction was stopped by replacing the medium with $0.1 \mathrm{M}$ formic acid. Supernatants were recovered, and IP was purified by ion exchange chromatography using DOWEX AG1-X8 resin (Biorad, Marnes-la-Coquette, France) in 96-well filter plates (ref:MAHVN4550; Millipore, Bedford, MA). Total radioactivity remaining in the membrane fractions was counted after treatment of cells with a solution containing $10 \%$ Triton $\mathrm{X}-100$ and $0.1 \mathrm{~N} \mathrm{NaOH}$. Radioactivity was quantified using Wallac 1450 MicroBeta liquid scintillation counter. Data were expressed as the amount of total IPs produced over the amount of radioactivity remaining in the membranes plus the produced IP. Unless stated otherwise, all data are means \pm SEM of at least three independent experiments and expressed in percentage of wild-type activity after a 30 min application of $1 \mathrm{~mm}$ GABA. The dose-response curves were fitted using the 
Graph Pad (San Diego, CA) Prism program and the following equation: $\mathrm{y}=\left[\left(\mathrm{y}_{\max }-\mathrm{y}_{\min }\right) /\left(1+\left(\mathrm{x} / \mathrm{EC}_{50}\right)^{\mathrm{nH}}\right)\right]+\mathrm{y}_{\min }$, where the $\mathrm{EC}_{50}$ is the concentration of the compound necessary to obtain $50 \%$ of the maximal effect, and $\mathrm{nH}$ is the Hill coefficient.

Ligand-binding assay. Ligand-binding assay on intact HEK 293 cells was performed as described previously using $0.1 \mathrm{~nm}\left[{ }^{125} \mathrm{I}\right] \mathrm{CGP} 64213$ (Galvez et al., 2001). Displacement curves were performed with at least seven different concentrations of the displacer, and the curves were fitted according to the equation: $\mathrm{y}=\left[\left(\mathrm{y}_{\max }-\mathrm{y}_{\min }\right) /\left(1+\left(\mathrm{x} / \mathrm{IC}_{50}\right)^{\mathrm{nH}}\right)\right]+\mathrm{y}_{\min }$, where the $\mathrm{IC}_{50}$ is the concentration of the compound that inhibits $50 \%$ of bound radioligand, and $\mathrm{nH}$ is the Hill coefficient. $K_{\mathrm{i}}$ values were calculated according to the equation $\mathrm{IC}_{50}=K_{\mathrm{i}}\left(1+[\mathrm{RL}] / K_{\mathrm{d}}\right)$, where $[\mathrm{RL}]$ and $K_{\mathrm{d}}$ are the concentration and dissociation constant of the radioligand, respectively. $K_{\mathrm{d}}$ was determined assuming $K_{\mathrm{i}}=K_{\mathrm{d}}$ in the case of CGP64213.

Western Blotting. Western blotting was performed as described previously (Kniazeff et al., 2002) using the rabbit polyclonal anti-HA antibody (Zymed, San Francisco, CA) and the anti-rabbit HRP antibody (Amersham, Saclay, France). The signal was revealed using an ECL assay.

Anti-HA ELISA assay for quantification of cell surface expression. Twenty-four hours after transfection $\left[10 \times 10^{6}\right.$ cells, HA-tagged $\mathrm{GABA}_{\mathrm{B} 1}(2 \mu \mathrm{g})$, and cMyc-tagged $\mathrm{GABA}_{\mathrm{B} 2}(2 \mu \mathrm{g})$ subunits], cells were fixed with $4 \%$ paraformaldehyde and then blocked with PBS plus $5 \%$ FBS. After a $30 \mathrm{~min}$ reaction with primary antibody (monoclonal anti-HA clone 3F10; $0.5 \mu \mathrm{g} / \mathrm{ml}$; Roche, Basel, Switzerland) in the same buffer, the goat anti-rat antibody coupled with HRP (Jackson Immunoresearch, West Grove, PA) was applied for $30 \mathrm{~min}$ at $1 \mu \mathrm{g} / \mathrm{ml}$. After intense washes with PBS, secondary antibody was detected and quantified instantaneously by chemiluminescence using Supersignal ELISA femto maximum sensitivity substrate (Pierce, Rockford, IL) and a Victor $^{2}$ luminescence counter (Wallac, Turku, Finland).

GTP- $\gamma-{ }^{35} S$ binding measurements. Cells were transfected using PolyFect transfection reagent (Qiagen, Hilden, Germany) under optimized conditions. Complexes were formed using a total amount of $8 \mu \mathrm{g}$ of plasmid DNA with $60 \mu \mathrm{l}$ of PolyFect in $300 \mu \mathrm{l}$ of serum-free antibioticfree DMEM for $10 \mathrm{~min}$ and then added to cells at $40-60 \%$ confluency. According to expression results, the amount of DNA is $2 \mu \mathrm{g}$ of $\mathrm{GABA}_{\mathrm{B} 1}$, $1 \mu \mathrm{g}$ of $\mathrm{GABA}_{\mathrm{B} 2}, 2 \mu \mathrm{g}$ of $\mathrm{G} \alpha \mathrm{o} 1 \mathrm{c}$, and $3 \mu \mathrm{g}$ of $\mathrm{pRK}_{6}$ for wild-type receptor and $2 \mu \mathrm{g}$ of $\mathrm{GABA}_{\mathrm{B} 1}, 2 \mu \mathrm{g}$ of $\mathrm{GABA}_{\mathrm{B} 2}, 2 \mu \mathrm{g}$ of $\mathrm{G} \alpha \mathrm{o} 1 \mathrm{c}$, and $2 \mu \mathrm{g}$ of $\mathrm{pRK}_{6}$ for $\mathrm{CC} 1$ and $\mathrm{CC} 2$ mutants.

Forty-eight hours after transfection, cells were scraped in lysis buffer (15 mm Tris, 2 mм MgCl2, and 0.3 mm EDTA, pH 7.4) and centrifuged twice. The pellet was resuspended in Tris ( $50 \mathrm{~mm}), \mathrm{MgCl} 2(3 \mathrm{~mm})$, EGTA $(0.2 \mathrm{~mm})$, and $\mathrm{NaCl}(60 \mathrm{~mm}), \mathrm{pH} 7.4$, using a potter. GTP- $\gamma-\left[{ }^{35} \mathrm{~S}\right](1099$ $\mathrm{Ci} / \mathrm{mmol}$; Amersham, Little Chalfont, UK) binding was performed in 96-well filtration plates (ref:MAFCN0B50; Millipore) equilibrated with Tris (50 mM) and $\mathrm{MgCl} 2$ ( $5 \mathrm{~mm}$ ), pH7.4. Membranes ( $5 \mu \mathrm{g} /$ well) were preincubated or not with GABA ( $15 \mathrm{~min} ; 1 \mathrm{~mm}$; final volume, $20 \mu \mathrm{l}$ ). The plate was incubated for $1 \mathrm{hr}$ at $30^{\circ} \mathrm{C}$ after the addition of $60 \mu \mathrm{l}$ of incubation buffer ( $50 \mathrm{~mm}$ Tris, $1 \mathrm{~mm}$ EDTA, $10 \mu \mathrm{M}$ GDP, $5 \mathrm{~mm} \mathrm{MgCl} 2,0.01$ $\mathrm{mg} / \mathrm{ml}$ leupeptine, $100 \mathrm{~mm} \mathrm{NaCl}$, and $\left.0.4 \mathrm{~nm} \mathrm{GTP}-\gamma-\left[{ }^{35} \mathrm{~S}\right]\right)$ and $20 \mu \mathrm{l}$ of $\mathrm{H}_{2} \mathrm{O}$. After vacuum filtration, plate-filter washing (three times with 250 $\mu \mathrm{l}$ of $50 \mathrm{~mm}$ Tris), and drying, the radioactivity was measured using a 1450 MicroBeta liquid scintillation counter (Wallac).

\section{Results}

Double cysteine mutations expected to lock the $\mathrm{GABA}_{\mathrm{B} 1}$ VFTM in a closed state generate constitutively active receptors

Based on three-dimensional models of the open and closed forms of the GABA $_{B 1}$ VFTM (Galvez et al., 1999, 2000a; Kniazeff et al., 2002), some positions were selected to introduce cysteines that could form a disulphide bridge in the closed state only. As depicted in Figure 2, the side chains of Ser247 or Ser246 from lobe I and those of Thr315 or Glu316 from lobe II are far apart in a model of the open form (Fig. 2a) but are in close proximity in the closed form (Fig. 2b,c). Indeed, in the double mutants S247CT315C (CC1) (Fig. 2d) and S246C-E316C (CC2) (data not
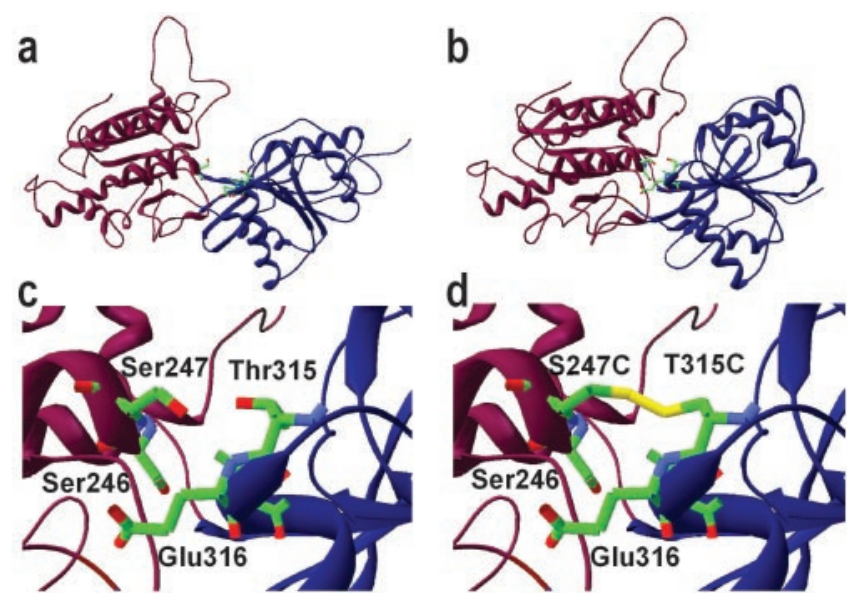

Figure 2. Three-dimensional models of the open $(a)$ and closed $(b)$ forms of the $\mathrm{GABA}_{\mathrm{B} 1}$ VFTM and possible covalent linkage of both lobes in a closed form by a disulphide bridge. Lobe I and lobe II are shown in red and blue ribbons, respectively. Residues subjected to mutagenesis are represented. A closer view of these residues in the closed form model is shown in c. In d, this same region is shown for the CC1 mutant receptor, in which Ser247 and Thr315 were mutated into cysteines.
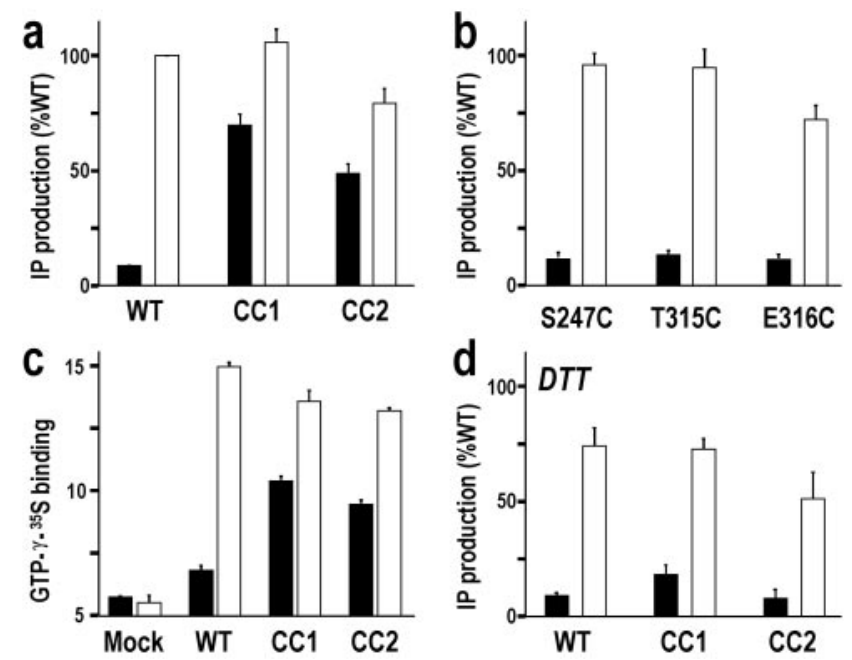

Figure 3. The double cysteine mutants display a DTT-sensitive constitutive activity. Basal and GABA (1 mM)-induced IP formation (black and white columns, respectively) were measured in cells expressing wild-type (WT) or double cysteine $\mathrm{GABA}_{\mathrm{B} 1}$ mutants, $\mathrm{CC} 1$ or $\mathrm{CC}(a)$, or single cysteine mutants S247C, T316C, and E316C (b). c, Same as in $a$, but the GTP $\gamma$ S binding was measured in membranes prepared from cells expressing the indicated $\mathrm{GABA}_{\mathrm{B} 1}$ subunit, the wild-type $\mathrm{GABA}_{\mathrm{B} 2}$ subunit, and the $\mathrm{G} 01 \alpha$ subunit. $d$, Same as in $a$, but after a 30 min treatment with $10 \mathrm{~mm}$ DTT, pH 8. Data are expressed as the percentage of the response obtained with the wild-type receptor after $1 \mathrm{~mm}$ GABA stimulation and are means \pm SEM of three independent experiments $(a, b, d)$ performed in triplicate. In $c$, data are means \pm SEM of triplicate determinations from one typical experiment.

shown), the distance between the sulfur atoms in the closed form models is compatible with the formation of a disulphide bond (1.9 and $2.1 \AA$ for $\mathrm{CC} 1$ and CC2, respectively). Double cysteine mutations were introduced in $\mathrm{GABA}_{\mathrm{B} 1}$, and the $\mathrm{CC} 1$ and CC2 mutants were analyzed for function after coexpression with wildtype $\mathrm{GABA}_{\mathrm{B} 2}$. Expression of the CC mutants in HEK 293 cells led to a high constitutive activity in the absence of agonist reaching $69.8 \pm 4.8 \%(\mathrm{CC} 1)$ and $48.8 \pm 4.3 \%(\mathrm{CC} 2)(n>3)$ of the maximal GABA-induced activity measured with the wild-type receptor (Fig. 3a). In contrast, no significant increase in constitutive activity can be detected with any of the single cysteine mutants 
Table 1. Potencies of the agonist GABA and the antagonist CGP64213 on wild-type (WT), CC1, CC2, and the single cysteine mutants measured either with a functional assay (IP production) or by displacement of [ ${ }^{125}$ I]CGP64213 binding under control condition or after DTT treatment

\begin{tabular}{|c|c|c|c|c|c|c|c|c|}
\hline & \multicolumn{4}{|l|}{ IP production } & \multicolumn{4}{|c|}{$\left[{ }^{125} \mathrm{I}\right]$ CGP64213 binding } \\
\hline & \multicolumn{2}{|l|}{ Control } & \multicolumn{2}{|l|}{ DTT } & \multicolumn{2}{|l|}{ Control } & \multicolumn{2}{|l|}{ DIT } \\
\hline & $\begin{array}{l}\mathrm{GABA} \\
\mathrm{EC}_{50}(\mu \mathrm{m})\end{array}$ & $\begin{array}{l}\text { CGP64213 } \\
\mathrm{IC}_{50}(\mathrm{~nm})\end{array}$ & $\begin{array}{l}\mathrm{GABA} \\
\mathrm{EC}_{50}(\mu \mathrm{M})\end{array}$ & $\begin{array}{l}\text { CGP64213 } \\
\mathrm{IC}_{50}(\mathrm{~nm})\end{array}$ & $\begin{array}{l}\text { GABA } \\
K_{\mathrm{i}}(\mu \mathrm{m})\end{array}$ & $\begin{array}{l}\text { CGP64213 } \\
K_{\mathrm{i}}(\mathrm{nm})\end{array}$ & $\begin{array}{l}\text { GABA } \\
K_{\mathrm{i}}(\mu \mathrm{m})\end{array}$ & $\begin{array}{l}\text { CGP64213 } \\
K_{\mathrm{i}}(\mathrm{nm})\end{array}$ \\
\hline WT & $0.23 \pm 0.02$ & $10.5 \pm 1.3$ & $0.34 \pm 0.06$ & $12.6 \pm 0.8$ & $4.74 \pm 0.61$ & $1.28 \pm 0.13$ & $2.75 \pm 0.97$ & $1.53 \pm 0.21$ \\
\hline $\mathrm{CC} 1$ & $0.43 \pm 0.07$ & $13.1 \pm 2.7$ & $0.26 \pm 0.08$ & $10.3 \pm 0.3$ & n.t. & $3.61 \pm 0.81$ & $1.59 \pm 0.34$ & $3.43 \pm 1.00$ \\
\hline $\mathrm{CC} 2$ & $0.33 \pm 0.07$ & $12.8 \pm 0.7$ & $0.29 \pm 0.05$ & $12.0 \pm 0.7$ & n.t. & $2.80 \pm 0.96$ & n.t. & n.t. \\
\hline S247C & $0.36 \pm 0.06$ & n.t. & n.t. & n.t. & $8.41 \pm 0.80$ & $1.67 \pm 0.73$ & n.t. & n.t. \\
\hline T315C & $0.28 \pm 0.06$ & n.t. & n.t. & n.t. & $9.50 \pm 0.46$ & $1.88 \pm 0.98$ & n.t. & n.t. \\
\hline E316C & $0.85 \pm 0.017$ & n.t. & n.t. & n.t. & $5.92 \pm 1.5$ & $2.13 \pm 0.73$ & n.t. & n.t. \\
\hline
\end{tabular}

Values are means \pm SEM of at least three independent experiments. n.t., Not tested.
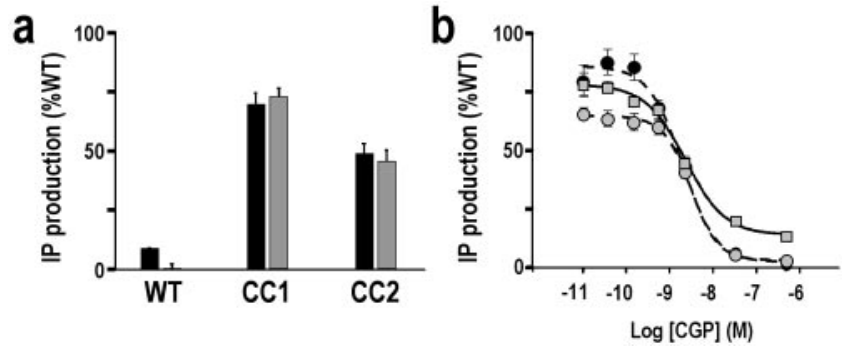

Figure 4. Constitutive activity of $\mathrm{CC}$ mutants is not inhibited by the $\mathrm{GABA}_{\mathrm{B}}$ competitive antagonist CGP64213. $a$, The high basal IP production measured with the $\mathrm{CC}$ mutants (black columns) is not inhibited by the $\mathrm{GABA}_{\mathrm{B}}$ antagonist (GP64213 (300 nm; gray columns), in contrast to the basal activity of the wild-type (WT) receptor. b, CGP64213 antagonizes with the same potency GABA (10 $\mu \mathrm{m}$ )-stimulated IP formation in cells expressing the wild-type $\mathrm{GABA}_{\mathrm{B}}$ receptor under control condition (black circles) or after DTT treatment (gray circles), or in cells expressing the CC1 mutant after DTT treatment (gray squares). Data are means \pm SEM of triplicates from one representative of three independent experiments.

(Fig. $3 b$ ). Such a property of the CC mutants can be detected using either the artificial coupling of the $\mathrm{GABA}_{\mathrm{B}}$ receptor to PLC with the chimeric Gqi9 protein (Fig. $3 a$ ), but also through the direct activation of Go protein as shown by GTP $\gamma\left[{ }^{35} \mathrm{~S}\right]$ binding (Fig. 3c).

\section{A disulphide bridge is involved in the constitutive activity of CC mutants}

In agreement with the involvement of a disulphide bond in the high constitutive activity of CC mutants, this activity can no longer be detected after reduction with DTT (Fig. 3d). This later effect does not result from a destabilization of any of the subunits attributable to reduction of native disulphide bonds for two reasons. First, DTT treatment of cells expressing the wild-type receptor had no significant effect on the basal activity, and only a small decrease in GABA-mediated response was observed (Fig. $3 d$ ). Second, after reduction, CC mutants can still be activated by agonists (Fig. $3 d$ ) with an affinity similar to that measured on the wild-type receptor (Table 1).

\section{The constitutive activity of CC mutants is not inhibited by} competitive antagonists

Competitive antagonists of mGluRs have been shown to bind in the open form of the VFTM, as illustrated with the mGlu1 (Tsuchiya et al., 2002) and mGlu8 (Bessis et al., 2002) receptors. Accordingly, a receptor locked in a closed state would not be expected to bind competitive antagonists. As shown in Figure $4 a$, the antagonist CGP64213 did not inhibit the basal activity of the CC mutants, whereas it was able to (1) inhibit the basal activity of
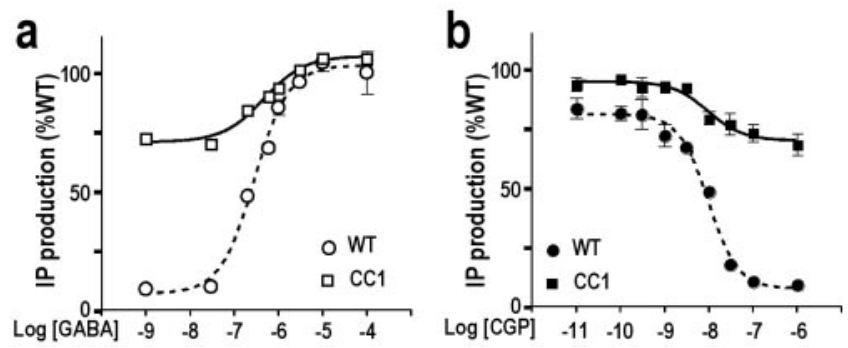

Figure 5. Cells expressing CC1 remain sensitive to both GABA and C GP64213 with the same potency as cells expressing wild-type (WT) receptor. Concentration-dependent effect of GABA (a) or (GP64213 (in the presence of $10 \mu \mathrm{M} G A B A)(b)$ on IP production in cells expressing wild-type (circles, dashed line) or CC1 (squares, solid line) $\mathrm{GABA}_{B}$ receptor. Data are means \pm SEM of triplicates from one representative of three independent experiments.

the wild-type receptor and (2) antagonize GABA-mediated responses of single cysteine mutants (Table 1). Moreover, after DTT treatment, this antagonist become effective in fully inhibiting GABA activation of the CC mutants (Fig. $4 b$ ) demonstrating that a disulphide bridge, but not the presence of the two cysteines, is responsible for the absence of antagonist action. These data show that the constitutively active receptor is locked in its active state and cannot return to the inactive antagonist-stabilized state.

\section{Not all surface-expressed CC1 mutants are locked in an active state}

Although high constitutive activity can be observed in cells expressing the CC1 mutant, GABA [as well as its chlorophenyl derivative baclofen (data not shown)] could still further increase the response with a potency identical to that measured on the wildtype receptor (Fig. 5a). This could result from the disulphide bridge-stabilized receptors being in a partially active conformation. However, the agonist-induced response can be fully antagonized by CGP64213 with the same potency as that measured on the wild-type receptor (Fig. 5b), indicating that the antagonist has access to agonist-activated receptors. These data suggest that there are two populations of receptors, some constitutively active and insensitive to antagonists, and some that can be activated by agonists and inhibited by CGP64213. In agreement with this proposal, a small amount of specific [ $\left.{ }^{125} \mathrm{I}\right] \mathrm{CGP} 64213$ binding can be detected in cells expressing the $\mathrm{CC} 1$ mutant, and this binding was largely increased after DTT treatment (approximately fivefold) in contrast to the wild-type receptor (Fig. $6 a$ ). This effect was not attributable to a change in the CGP64213 affinity because the same $K_{\mathrm{i}}$ values for this antagonist could be determined by displacement studies on CC1-expressing cells before and after DTT treatment (Table 1). This shows that reduction reveals new bind- 

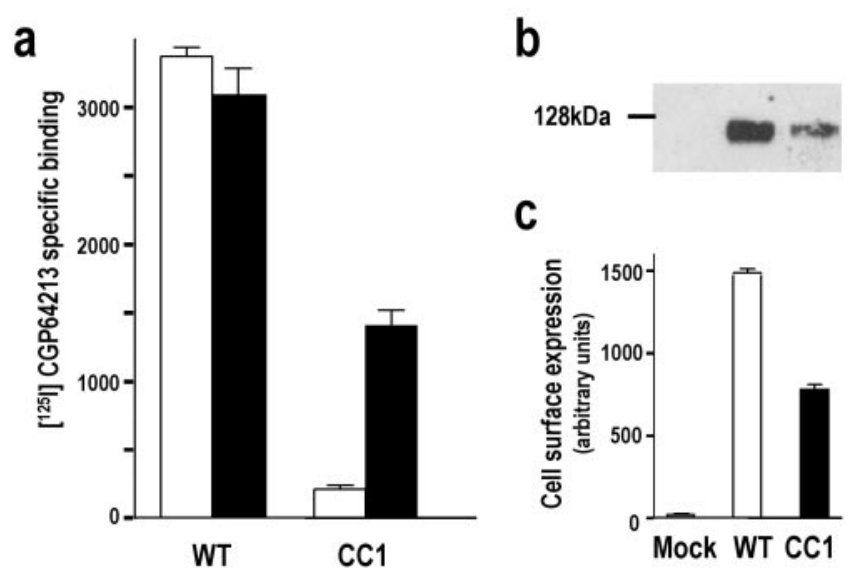

Figure 6. Cells expressing $C\left(1 \mathrm{GABA}_{B}\right.$ receptors possess CGP64213-binding sites at their surface, and new sites are unmasked after DTT treatment. $\left.a,\left[{ }^{125}\right]\right]$ CGP64213 binding under control condition (white column) or after DTT treatment (black column) on intact cells expressing $G_{A B A_{B 2}}$ and wild-type (WT) or $C C 1 G_{A B A_{B 1}}$ subunits. Data are means of triplicates from one representative of three independent experiments. $b$, Western blot on total membranes of cells mock-transfected or transfected with plasmid expressing HA-tagged wild-type or CC1 mutant. c, Quantification of cell surface expression of wild-type (WT) and CC1 mutant $\mathrm{GABA}_{B 1}$ subunit using an ELISA assay in HEK 293-transfected cells.

ing sites in cells expressing the CC1 mutant. Finally, the specific binding of $\left[{ }^{125} \mathrm{I}\right]$ CGP64213 after DTT treatment represented half of that determined on cells expressing the wild-type receptor, in agreement with a twofold lower expression level of this receptor (Fig. 6b,c). Therefore, most CGP64213-binding sites have been unmasked after DTT reduction. Taken together, these data show that $75.5 \pm 6.9 \%$ of the binding sites in cells expressing the CC1 mutant are inaccessible to CGP64213 because of a disulphide bridge. Thus, the effect of GABA on these cells likely results from the $25 \%$ remaining receptors because this effect is fully inhibited by this antagonist. Another conclusion from these data are that GABA is unlikely able to activate the constitutively active, CGP64213-insensitive form of the receptor.

We then examined whether the proportion of disulphidelocked receptors could be modulated by oxidizing agents $5,5^{\prime}$ dithio-bis(2-nitrobenzoic acid) or $\mathrm{Cu}$-Phenantroline by agonists that are expected to stabilize the closed state or by antagonists expected to prevent the formation of the closed state. None of these treatments alone or in combination lead to a modification of constitutive activity (Fig. 7). Moreover, after DTT treatment, constitutive activity of the CC1 mutant could not be restored after 30 min of exposure to the oxidizing agents (data not shown). This suggests that all disulphide-locked receptors are formed inside the cells rather than after plasma membrane insertion.

\section{Constitutive activity of the disulphide-locked CC1 mutant is} close to the agonist-induced activity of the wild-type receptor We then examined whether the constitutive activity of the CC1 mutant corresponds to a fully active form of the receptor. Surface expression was determined with an ELISA assay, and second messenger formation was measured in cells expressing various amount of the $\mathrm{GABA}_{\mathrm{B}}$ heterodimer. A saturating curve was observed, and the slope at the origin of the curves is indicative of the specific activity of the receptor (amount of second messengers produced per receptor) (Fig. 8). In the absence of agonist, the specific activity of $\mathrm{CC} 1$ is about half the specific activity of the wild-type receptor activated by GABA $\left(0.7 \times 10^{-3}\right.$ and $1.4 \times$ $10^{-3}$ arbitrary units, respectively), but, after DTT treatment, this
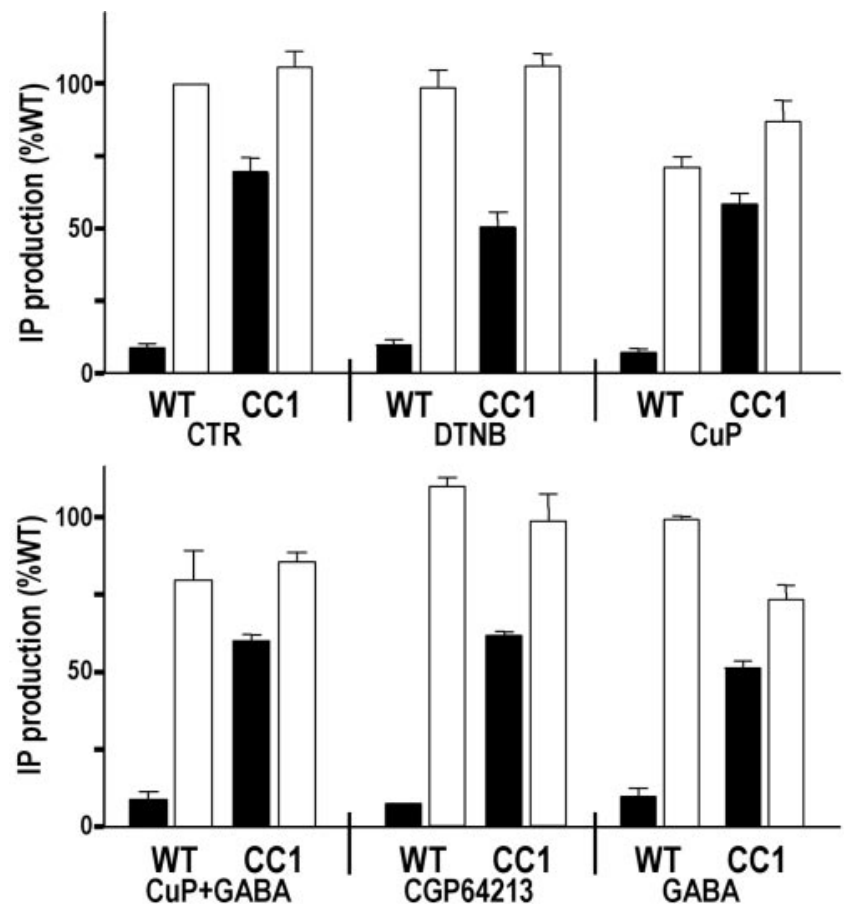

Figure 7. Neither oxidizing treatment nor overnight incubation with agonist or antagonist increase the constitutive activity. Basal and GABA ( $1 \mathrm{~mm}$ )-induced IP formation (black and white columns, respectively) were measured under control (CTR) or after various treatment: $0.5 \mathrm{~mm}$ 5,5'-dithio-bis(2-nitrobenzoic acid (DTNB) for $30 \mathrm{~min}, 1 \mathrm{~mm} \mathrm{CuSO}_{4}$ plus $4 \mathrm{~mm}$ phenanthroline (CuP) for $30 \mathrm{~min}$, CuP in the presence of $10 \mu \mathrm{m} \mathrm{GABA}$ for $30 \mathrm{~min}$, and overnight incubation with CGP64213 (100 nM) or GABA (1 mM) applied immediately after transfection.

activity is decreased to the level of the basal activity of the wildtype receptor. Because only $75 \%$ of the $\mathrm{CC} 1$ receptors are expected to be stabilized in an active form by a disulphide bridge (see above), this indicates that the specific activity of the constitutively active form of $\mathrm{CC} 1$ receptors is close to the specific activity of the agonist-activated wild-type receptors $\left(1.0 \times 10^{-3}\right.$ and $1.4 \times 10^{-3}$ arbitrary units, respectively).

The curves obtained clearly saturate, indicating a maximal IP formation could be measured with a nonsaturating amount of receptors expressed at the cell surface. This is in contrast to what can be observed under similar conditions with the Gq-coupled mGlu5 receptor (Goudet et al., 2004). This may, therefore, result from the use of the chimeric G-protein $\alpha$ subunit Gqi9 cotransfected with the receptor to make it able to activate PLC. It is possible that either the amount of Gqi9 or endogenous $\beta \gamma$ subunits is limiting when the receptor is overexpressed.

\section{Double cysteine mutations in the $\mathrm{GABA}_{\mathrm{B} 2}$ VFTM does not influence receptor function}

Can the closure of the $\mathrm{GABA}_{\mathrm{B} 2}$ VFTM also lead to receptor activation? To test this possibility, cysteines were introduced in the $\mathrm{GABA}_{\mathrm{B} 2}$ VFTM at the same positions as in $\mathrm{GABA}_{\mathrm{B} 1}$, but neither constitutive activity nor changes in agonist efficacy and potency were detected (data not shown). To examine whether such cysteines could form a disulphide bond in the GABA $\mathrm{B}_{2}$ VFTM, and as such to lock this domain in a closed state, Western blot experiments were conducted under reducing and nonreducing (100 mM DTT, pH 8) conditions. Such an experiment performed with the full-length receptor did not lead to a clear conclusion, likely because of the large size of these receptor subunits. As such, constructs were created ( $\Delta \mathrm{GB} 1$ and $\Delta \mathrm{GB} 2)$, in which a stop codon 


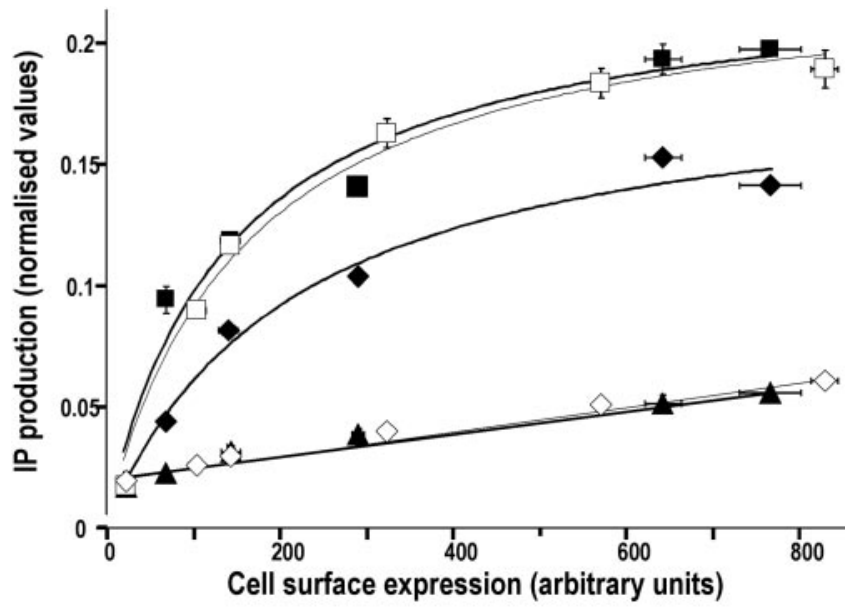

Figure 8. Constitutive activity of $\mathrm{CC} 1$ mutant receptors is close to GABA-mediated activity of the wild-type receptor. Basal (diamonds) and GABA-mediated (squares) IP formation were measured in cells transfected with HA-tagged wild-type (open symbols, thin lines) or CC1 mutant (filled symbols, bold lines) $\mathrm{GABA}_{\mathrm{B} 1}$ subunit $(2 \mu \mathrm{g})$ and various amounts of $\mathrm{GABA}_{\mathrm{B2}}{ }^{-}$ expressing plasmids $(0.05-2 \mu \mathrm{g})$. The amount of $\mathrm{GABA}_{B}$ receptors at the cell surface was measured using ELISA and a $\mathrm{HA}$ antibody. Basal IP formation in cells expressing various amounts of $C\left(1\right.$ mutant containing $G_{A B A}$ receptor was also measured after DTT treatment (closed triangles). Data are means \pm SEM of triplicate determinations from a single experiment. Similar data were obtained in three independent experiments. Data points were fitted according to the saturation equation: IP $=\mathbb{I P m a x} \times \operatorname{Exp} /(C$ te $+\operatorname{Exp})$, where IP is the amount of IPs produced under the indicated condition, IPmax is the maximal IP response obtained with a high expression level of the receptor, Exp is the signal obtained with the ELISA, and Cte is a constant.

was introduced after TM1, leading to the expression of the VFTM attached to the membrane by the first transmembrane domain. As shown in Figure 9, these constructs migrated faster under nonreducing conditions, in agreement with the proposed existence of native disulphide bridges in the VFTM of both GABA $_{\mathrm{B} 1}$ and $\mathrm{GABA}_{\mathrm{B} 2}$ (Galvez et al., 2000a; Kniazeff et al., 2002). Of interest, both $\Delta$ GB1-CC and $\Delta$ GB2-CC migrated slightly faster than the wild types under the nonreducing condition, consistent with the existence of an additional disulphide bridge in these constructs.

\section{Discussion}

The present study indicates that the introduction of two cysteines expected to lock the $\mathrm{GABA}_{\mathrm{B} 1}$ VFTM in a closed form generates a constitutively active heterodimeric $\mathrm{GABA}_{\mathrm{B}}$ receptor.

A disulphide bond locks the $\mathrm{GABA}_{\mathrm{B}}$ receptor in an active state GPCRs are assumed to oscillate between various inactive (R) and active $\left(\mathrm{R}^{*}\right)$ conformations (Lefkowitz, 1993; Samama et al., 1993; Leff, 1995; Farrens et al., 1996; Christopoulos and Kenakin, 2002), the latter being stabilized by agonists, whereas the former is stabilized by inverse agonists. Mutations have been identified that lead to constitutive activity (Lefkowitz, 1993; Samama et al., 1993; Leff, 1995; Christopoulos and Kenakin, 2002; Parnot et al., 2002), but these have been shown to destabilize the inactive conformations rather than to stabilize an active one (Parnot et al., 2002). As such, these mutations are expected to displace the $\mathrm{R} \leftrightarrow \mathrm{R}^{\star}$ equilibrium toward $\mathrm{R}^{\star}$, as demonstrated by the inhibition of constitutive activity by inverse agonists, but did not bring much information on the active conformation of the receptor. The $\mathrm{GABA}_{\mathrm{B} 1} \mathrm{CC}$ mutants appear to be locked in an active state through the formation of an additional disulphide bond. Indeed, the $\mathrm{R} \leftrightarrow \mathrm{R}^{\star}$ equilibrium seems to no longer exist because the receptor cannot return to the inactive state even in the presence of

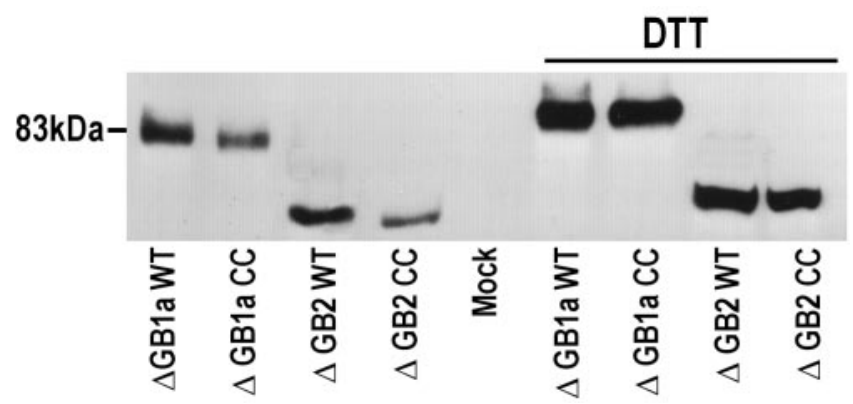

Figure 9. Migration of the VFTMs of $\mathrm{GABA}_{B 1}$ and $\mathrm{GABA}_{\mathrm{B} 2}$ is affected by the presence of the two additional cysteines. Total proteins from cells expressing the wild-type (WT) or the CC version of $\triangle G B 1$ or $\triangle G B 2\left(G A B A_{B 1}\right.$ and $G A B A_{B 2}$, in which a stop codon has been introduced after TM1) were separated on an acrylamide gel under nonreducing conditions or after treatment with $100 \mathrm{~mm}$ DTT, pH 8. After transfer, the proteins were detected using an anti-HA antibody directed against the HA epitope inserted after the signal peptide. Data shown are representative of three independent experiments.

a high concentration of the inverse agonist CGP64213. Only DTT treatment allowed the receptor to return to an inactive state. This represents the first example of a constitutively active form of a GPCR resulting from the locking of an active state.

\section{A disulphide bond locks the $\mathrm{GABA}_{\mathrm{B} 1}$ VFTM in a closed state}

Several data are consistent with the two cysteines introduced in the $\mathrm{CC} 1$ and $\mathrm{CC} 2$ mutants involved in a disulphide bridge that locks the $\mathrm{GABA}_{\mathrm{B} 1}$ VFTM in a closed state. First, the VFTM of the $\mathrm{CC} 1$ mutant migrates faster than the wild type in acrylamide gels under nonreducing conditions. Second, the distance between the two sulfydryl groups introduced is consistent with the formation of a disulphide bond in a closed form model of the $\mathrm{GABA}_{\mathrm{B} 1}$ VFTM only. Third, the $\mathrm{GABA}_{\mathrm{B}}$ antagonist CGP64213 is unable to (1) inhibit the constitutive activity of the CC mutants and (2) bind on the disulphide-locked receptor, although this antagonist can bind and exert its normal antagonist action after DTT treatment. Indeed, as observed for the mGlul (Tsuchiya et al., 2002) and mGlu8 (Bessis et al., 2002) receptors, many $\mathrm{GABA}_{\mathrm{B}}$ competitive antagonists are larger than agonists and cannot fit into a closed form model of the binding site. Finally, modeling and mutagenesis studies suggested that the active form of the GABA $\mathrm{B}_{1}$ VFTM corresponds to a closed form because residues from both lobes are involved in agonist binding (Galvez et al., 1999, 2000a; Bernard et al., 2001; Costantino et al., 2001; Kniazeff et al., 2002).

However, the absence of modulation by oxidants or ligands expected to help or prevent the formation of the disulphide bridge was surprising. Accordingly, the disulphide-locked receptors are likely formed during the synthesis of the receptor in the endoplasmic reticulum. When the receptor is correctly folded and at the cell surface, in the absence of the preformed disulphide bond or after its reduction with DTT, the sulfydryl groups may not be in a correct orientation to spontaneously form a disulphide bond. Indeed, in our three-dimensional model, the side chains of mutated residues had to be reoriented manually for the disulphide bridge to form. Moreover, this area in the $\mathrm{GABA}_{\mathrm{B} 1}$ VFTM has been proposed to constitute a $\mathrm{Ca}^{2+}$-binding site (Galvez et al., 2000b; Costantino et al., 2001), thus stabilizing a precise position of the side chains of the surrounding residues and possibly preventing the formation of a disulphide bond.

The disulphide-locked active state is close to the agoniststabilized active state

Although cells expressing the CC1 or CC2 mutants display a high constitutive PLC activity, IP formation could still be increased by 
$\mathrm{GABA}_{\mathrm{B}}$ agonists. This may seem surprising in the case of the CC2 mutant because Ser246 (mutated into Cys in this mutant) has been proposed previously to form an $\mathrm{H}$-bond with the carboxylic function of $\mathrm{GABA}_{\mathrm{B}}$ ligands (Galvez et al., 2000a; Bernard et al., 2001; Costantino et al., 2001; Kniazeff et al., 2002). However, because an $\mathrm{SH}$ group can also form $\mathrm{H}$-bonds, it is likely that the replacement of the $\mathrm{OH}$ group of Ser246 by an $\mathrm{SH}$ group has minor effect on ligand-binding affinities.

In the case of the ionotropic glutamate receptor subtypes, partial agonists stabilized a partially closed form of the glutamate-binding domain (Armstrong and Gouaux, 2000; Armstrong et al., 2003). Therefore, one possibility to explain the agonist-induced response in CC mutant-expressing cells was that the disulphide bond locked the receptor in a partially closed form that could be closed further in the presence of agonist. However, our data indicate that this is unlikely the case but rather that the agonist-mediated response is attributable to a certain fraction of the receptors at the cell surface that are not locked in their active state by a disulphide bridge. Indeed, a fraction of the CC mutants can bind with a normal affinity to the antagonist CGP64213, and the agonist-induced activity can be inhibited by the antagonist with a wild-type $K_{\mathrm{i}}$. Taking this into consideration, together with the receptor density at the cell surface, we estimated that the specific activity of the constitutively active disulphide-locked CC1 mutant is close to that of the agonist-stabilized form of the wild-type receptor. This suggests that the conformation of the disulphide-locked CC1 VFTM is close to that of the agonistbound form of the wild-type receptor.

\section{Comparison with mGlul and ANP receptors}

As shown in Figure $1 a$, the $\mathrm{GABA}_{\mathrm{B}}$ VFTMs are as distant from the mGlu1 VFTM than from any other VFTMs. Moreover, the large insertions found in mGlu VFTMs and conserved in the related $\mathrm{Ca}^{2+}$-sensing, pheromone, and taste receptors are not found in the $\mathrm{GABA}_{\mathrm{B}}$ VFTMs. Finally, whereas the mGlu-like receptors possess a cysteine-rich domain that connects their VFTM to the heptahelical domain, the $\mathrm{GABA}_{\mathrm{B}}$ subunits do not. In contrast, the $G_{A B A}$ VFTMs share a significant higher similarity with the VFTM of the monotopic receptor RTK1 (Vicogne et al., 2003), leaving open the possibility that the dimer of VFTMs of the dimeric $\mathrm{GABA}_{\mathrm{B}}$ receptor functions like those of dimeric monotopic receptors. However, in the case of the monotopic receptor for the natriuretic peptide, both VFTMs are in a closed conformation even in the inactive state (He et al., 2001; van den Akker, 2001) (Fig. 1c), whereas agonists seem to stabilize a closed form of the VFTM in the case of the mGluRs (Kunishima et al., 2000; Bessis et al., 2002; Tsuchiya et al., 2002) (Fig. 1b). Accordingly, our data suggest the dimer of $\mathrm{GABA}_{\mathrm{B}}$ VFTMs functions like that of mGluRs despite some structural dissimilarities between these two types of receptors.

\section{Role of $\mathrm{GABA}_{\mathrm{B} 2}$ VFTM in $\mathrm{GABA}_{\mathrm{B}}$ receptor activation}

$\mathrm{GABA}_{\mathrm{B} 2}$ possesses a VFTM similar to that of $\mathrm{GABA}_{\mathrm{B} 1}$. Although required for $\mathrm{GABA}_{\mathrm{B}}$ receptor activation (Galvez et al., 2001; Margeta-Mitrovic et al., 2001a), the GABA $_{\mathrm{B} 2}$ VFTM does not seem to bind any ligand (Kniazeff et al., 2002). Our data show that introduction of two cysteines at the same position as in $\mathrm{CC} 1$ and CC2 mutants in the GABA ${ }_{B 2}$ VFTM does not change the properties of the heteromeric $\mathrm{GABA}_{\mathrm{B}}$ receptor. However, as observed with the $\mathrm{GABA}_{\mathrm{B} 1} \mathrm{CC}$ mutant, the $\mathrm{GABA}_{\mathrm{B} 2} \mathrm{CC}$ migrates faster than the wild type under nonreducing conditions, consistent with the existence of an additional disulphide bridge in this mutant. This suggests that the closure of $\mathrm{GABA}_{\mathrm{B} 2}$ is not sufficient to activate the receptor. Indeed, either $\mathrm{GABA}_{\mathrm{B} 2} \mathrm{VFTM}$ is always closed or the closure of $\mathrm{GABA}_{\mathrm{B} 2}$ VFTM has no detectable effect on the function of the receptor. This is consistent with the closure of $\mathrm{GABA}_{\mathrm{B} 1}$ VFTM being sufficient for $\mathrm{GABA}_{\mathrm{B}}$ receptor activation, in agreement with our proposal that $\mathrm{GABA}_{\mathrm{B}}$ agonists bind in the $\mathrm{GABA}_{\mathrm{B} 1}$ VFTM only (Kniazeff et al., 2002). Moreover, our data also suggest that even an artificial ligand interacting in the cleft of $\mathrm{GABA}_{\mathrm{B} 2}$ is not expected to have an important effect on the functioning of the heterodimer.

\section{Allostery between the four main domains of the heterodimeric $\mathrm{GABA}_{\mathrm{B}}$ receptor}

Although GABA binds to the $\mathrm{GABA}_{\mathrm{B} 1}$ VFTM only, the $\mathrm{GABA}_{\mathrm{B} 2}$ 7TM is critical for G-protein coupling (Galvez et al., 2001; Margeta-Mitrovic et al., 2001b; Robbins et al., 2001; Duthey et al., 2002). How can the closure of the $\mathrm{GABA}_{\mathrm{B} 1}$ VFTM lead to the change in conformation of the $\mathrm{GABA}_{\mathrm{B} 2} 7 \mathrm{TM}$ domain necessary for $\mathrm{G}$-protein activation? In the case of mGluRs, it has been proposed that the change in the relative orientation of the two VFTMs, observed on glutamate binding, may be required for activation (Kunishima et al., 2000; Jensen et al., 2001, 2002). Based on this hypothesis, the closure of the GABA $\mathrm{B}_{1}$ VFTM possibly leads to a change in the relative orientation of the two VFTMs in the heterodimer as proposed for the mGlul receptor, no matter whether the $\mathrm{GABA}_{\mathrm{B} 2}$ VFTM is in a closed or open conformation.

\section{Conclusion}

Our present study brings much information on how GABA activates the $\mathrm{GABA}_{B}$ receptor and on the specific roles played by each subunit in this heteromeric receptor. Moreover, such information may be of interest for the understanding of the activation process of many other GPCRs, Indeed, the rhodopsin-like class I GPCRs also form dimers (Bouvier, 2001; Fotiadis et al., 2003). It is still unknown whether such dimers are required for activation and whether, in such a case, agonist occupation of a single protomer is sufficient for full activation of the receptor. Taking into account our data and the fact that retina can detect a single photon although rhodopsin forms oligomers of dimers (Fotiadis et al., 2003; Liang et al., 2003), one may propose that an initial change in conformation in a single subunit may be sufficient to trigger the activation of some dimeric GPCRs.

\section{References}

Armstrong N, Gouaux E (2000) Mechanisms for activation and antagonism of an AMPA-sensitive glutamate receptor: crystal structures of the GluR2 ligand binding core. Neuron 28:165-181.

Armstrong N, Mayer M, Gouaux E (2003) Tuning activation of the AMPAsensitive GluR2 ion channel by genetic adjustment of agonist-induced conformational changes. Proc Natl Acad Sci USA 100:5736-5741.

Bernard P, Guedin D, Hibert M (2001) Molecular modeling of the GABA/ GABA(B) receptor complex. J Med Chem 44:27-35.

Bessis A-S, Rondard P, Gaven F, Brabet I, Triballeau N, Prézeau L, Acher F, Pin J-P (2002) Closure of the Venus flytrap module of mGlu8 receptor and the activation process: insights from mutations converting antagonists into agonists. Proc Natl Acad Sci USA 99:11097-11102.

Bockaert J, Pin JP (1999) Molecular tinkering of G protein-coupled receptors: an evolutionary success. EMBO J 18:1723-1729.

Bouvier M (2001) Oligomerization of G-protein-coupled transmitter receptors. Nat Rev Neurosci 2:274-286.

Brabet I, Parmentier ML, De Colle C, Bockaert J, Acher F, Pin JP (1998) Comparative effect of L-CCG-I, DCG-IV and gamma-carboxy-Lglutamate on all cloned metabotropic glutamate receptor subtypes. Neuropharmacology 37:1043-1051.

Chengalvala M, Kostek B, Frail DE (1999) A multi-well filtration assay for 
quantitation of inositol phosphates in biological samples. J Biochem Biophys Methods 38:163-170.

Christopoulos A, Kenakin T (2002) G protein-coupled receptor allosterism and complexing. Pharmacol Rev 54:323-374.

Costantino G, Macchiarulo A, Entrena Guadix A, Pellicciari R (2001) QSAR and molecular modeling studies of baclofen analogues as GABA(B) agonists. Insights into the role of the aromatic moiety in $\mathrm{GABA}(\mathrm{B})$ binding and activation. J Med Chem 44:1827-1832.

Duthey B, Caudron S, Perroy J, Bettler B, Fagni L, Pin J-P, Prézeau L (2002) A single subunit (GB2) is required for G-protein activation by the heterodimeric GABAB receptor. J Biol Chem 277:3236-3241.

Farrens DL, Altenbach C, Yang K, Hubbell WL, Khorana HG (1996) Requirement of rigid-body motion of transmembrane helices for light activation of rhodopsin. Science 274:768-770.

Felder CB, Graul RC, Lee AY, Merkle HP, Sadee W (1999) The Venus flytrap of periplasmic binding proteins: an ancient protein module present in multiple drug receptors. AAPS PharmSci 1:1-20.

Fotiadis D, Liang Y, Filipek S, Saperstein DA, Engel A, Palczewski K (2003) Atomic-force microscopy: rhodopsin dimers in native disc membranes. Nature 421:127-128.

Franek M, Pagano A, Kaupmann K, Bettler B, Pin J-P, Blahos II J (1999) The heteromeric GABA-B receptor recognizes G-protein $\alpha$ subunit C-termini. Neuropharmacology 38:1657-1666.

Fredriksson R, Lagerstrom MC, Lundin LG, Schioth HB (2003) The G-protein-coupled receptors in the human genome form five main families. Phylogenetic analysis, paralogon groups, and fingerprints. Mol Pharmacol 63:1256-1272.

Galvez T, Parmentier ML, Joly C, Malitschek B, Kaupmann K, Kuhn R, Bittiger H, Froestl W, Bettler B, Pin JP (1999) Mutagenesis and modeling of the GABAB receptor extracellular domain support a Venus flytrap mechanism for ligand binding. J Biol Chem 274:13362-13369.

Galvez T, Prezeau L, Milioti G, Franek M, Joly C, Froestl W, Bettler B, Bertrand HO, Blahos J, Pin JP (2000a) Mapping the agonist-binding site of GABAB type 1 subunit sheds light on the activation process of GABAB receptors. J Biol Chem 275:41166-41174.

Galvez T, Urwyler S, Prézeau L, Mosbacher J, Joly C, Malitschek B, Heid J, Brabet I, Froestl W, Bettler B, Kaupmann K, Pin J-P (2000b) $\mathrm{Ca}^{2+}$ requirement for high affinity $\gamma$-aminobutyric acid (GABA) binding at $\mathrm{GABA}_{\mathrm{B}}$ receptors: involvement of serine 269 of the $G A B A_{B} R 1$ subunit. Mol Pharmacol 57:419-426.

Galvez T, Duthey B, Kniazeff J, Blahos J, Rovelli G, Bettler B, Prezeau L, Pin JP (2001) Allosteric interactions between GB1 and GB2 subunits are required for optimal GABA(B) receptor function. EMBO J 20:2152-2159.

Goudet C, Gaven F, Kniazeff J, Vol C, Liu J, Cohen-Gonsaud M, Acher F, Prézeau L, Pin JP (2004) Heptahelical domain of metabotropic glutamate receptor 5 behaves like rhodopsin-like receptors. Proc Natl Acad Sci USA, in press.

Guex N, Peitsch MC (1997) SWISS-MODEL and the Swiss-PdbViewer: an environment for comparative protein modeling. Electrophoresis 18:2714-2723.

He X-L, Chow D-C, Martick MM, Garcia KC (2001) Allosteric activation of a spring-loaded natriuretic peptide receptor dimer by hormone. Science 293:1657-1662.

Jensen AA, Sheppard PO, Jensen LB, O’Hara PJ, Bräuner-Osborne H (2001) Construction of a high affinity zinc binding site in the metabotropic glutamate receptor mGluR1: noncompetitive antagonism from the aminoterminal domain of a family C G-protein-coupled receptor. J Biol Chem 276:10110-10118.

Jensen AA, Greenwood JR, Bräuner-Osborne H (2002) The dance of the clams: twists and turns in the family C GPCR homodimer. Trends Pharmacol Sci 23:491-493.

Jones KA, Borowsky B, Tamm JA, Craig DA, Durkin MM, Dai M, Yao WJ, Johnson M, Gunwaldsen C, Huang LY, Tang C, Shen Q, Salon JA, Morse K, Laz T, Smith KE, Nagarathnam D, Noble SA, Branchek TA, Gerald C (1998) GABA(B) receptors function as a heteromeric assembly of the subunits GABA(B)R1 and GABA(B)R2. Nature 396:674-679.

Kaupmann K, Malitschek B, Schuler V, Heid J, Froestl W, Beck P, Mosbacher J, Bischoff S, Kulik A, Shigemoto R, Karschin A, Bettler B (1998) $\mathrm{GABA}(\mathrm{B})$-receptor subtypes assemble into functional heteromeric complexes. Nature 396:683-687.

Kniazeff J, Galvez T, Labesse G, Pin JP (2002) No ligand binding in the GB2 subunit of the GABA(B) receptor is required for activation and allosteric interaction between the subunits. J Neurosci 22:7352-7361.

Kolakowski LF (1994) GCRDb: a G-protein-coupled receptor database. Receptors Channels 2:1-7.

Kunishima N, Shimada Y, Tsuji Y, Sato T, Yamamoto M, Kumasaka T, Nakanishi S, Jingami H, Morikawa K (2000) Structural basis of glutamate recognition by a dimeric metabotropic glutamate receptor. Nature 407:971-977.

Leff P (1995) The two-state model of receptor activation. Trends Pharmacol Sci 16:89-97.

Lefkowitz RJ (1993) Turned on to ill effect. Nature 365:603-604.

Liang Y, Fotiadis D, Filipek S, Saperstein DA, Palczewski K, Engel A (2003) Organization of the $G$ protein-coupled receptors rhodopsin and opsin in native membranes. J Biol Chem 278:21655-21662.

Margeta-Mitrovic M, Jan YN, Jan LY (2000) A trafficking checkpoint controls GABA(B) receptor heterodimerization. Neuron 27:97-106.

Margeta-Mitrovic M, Jan YN, Jan LY (2001a) Ligand-induced signal transduction within heterodimeric GABA(B) receptor. Proc Natl Acad Sci USA 98:14643-14648.

Margeta-Mitrovic M, Jan YN, Jan LY (2001b) Function of GB1 and GB2 subunits in $\mathrm{G}$ protein coupling of GABA(B) receptors. Proc Natl Acad Sci USA 98:14649-14654.

O’Hara PJ, Sheppard PO, Thøgersen H, Venezia D, Haldeman BA, McGrane V, Houamed KM, Thomsen C, Gilbert TL, Mulvihill ER (1993) The ligand-binding domain in metabotropic glutamate receptors is related to bacterial periplasmic binding proteins. Neuron 11:41-52.

Pagano A, Rovelli G, Mosbacher J, Lohmann T, Duthey B, Stauffer D, Ristig D, Schuler V, Meigel I, Lampert C, Stein T, Prézeau L, Blahos J, Pin J-P, Froestl W, Kuhn R, Heid J, Kaupmann K, Bettler B (2001) C-terminal interaction is essential for surface trafficking but not for heteromeric assembly of $\mathrm{GABA}_{\mathrm{B}}$ receptors. J Neurosci 21:1189-1202.

Page RDM (1996) TreeView: an application to display phylogenetic trees on personal computers. Comput Appl Biosci 12:357-358.

Paoletti P, Perin-Dureau F, Fayyazuddin A, Le Goff A, Callebaut I, Neyton J (2000) Molecular organization of a zinc binding N-terminal modulatory domain in a NMDA receptor subunit. Neuron 28:911-925.

Parnot C, Miserey-Lenkei S, Bardin S, Corvol P, Clauser E (2002) Lessons from constitutively active mutants of $\mathrm{G}$ protein-coupled receptors. Trends Endocrinol Metab 13:336-343.

Pin JP, Galvez T, Prezeau L (2003) Evolution, structure, and activation mechanism of family $3 / \mathrm{C}$ G-protein-coupled receptors. Pharmacol Ther 98:325-354.

Robbins MJ, Calver AR, Filippov AK, Hirst WD, Russell RB, Wood MD, Nasir S, Couve A, Brown DA, Moss SJ, Pangalos MN (2001) GABA $_{B 2}$ is essential for G-protein coupling of the $\mathrm{GABA}_{\mathrm{B}}$ receptor heterodimer. J Neurosci 21:8043-8052.

Saitou N, Nei M (1987) The neighbor-joining method: a new method for reconstructing phylogenetic trees. Mol Biol Evol 4:406-425.

Sali A, Blundell TL (1993) Comparative protein modelling by satisfaction of spatial restraints. J Mol Biol 234:779-815.

Samama P, Cotecchia S, Costa T, Lefkowitz RJ (1993) A mutation-induced activated state of the $\beta 2$-adrenergic receptor. J Biol Chem 268:4625-4636.

Takahashi K, Tsuchida K, Tanabe Y, Masu M, Nakanishi S (1993) Role of the large extracellular domain of metabotropic glutamate receptors in agonist selectivity determination. J Biol Chem 268:19341-19345.

Thompson JD, Higgins DG, Gibson TJ (1994) Clustal W: improving the sensitivity of progressive multiple sequence alignment through sequence weighting, position-specific gap penalties and weight matrix choice. Nucleic Acids Res 22:4673-4680.

Tsuchiya D, Kunishima N, Kamiya N, Jingami H, Morikawa K (2002) Structural views of the ligand-binding cores of a metabotropic glutamate receptor complexed with an antagonist and both glutamate and $\mathrm{Gd}^{3+}$. Proc Natl Acad Sci USA 99:2660-2665.

van den Akker F (2001) Structural insights into the ligand binding domains of membrane bound guanylyl cyclases and natriuretic peptide receptors. J Mol Biol 311:923-937.

Vicogne J, Pin JP, Lardans V, Capron M, Noel C, Dissous C (2003) An unusual receptor tyrosine kinase of Schistosoma mansoni contains a Venus flytrap module. Mol Biochem Parasitol 126:51-62.

White JH, Wise A, Main MJ, Green A, Fraser NJ, Disney GH, Barnes AA, Emson P, Foord SM, Marshall FH (1998) Heterodimerization is required for the formation of a functional GABA(B) receptor. Nature 396: $679-682$. 